\title{
HRM practice in commercial banks: A case study of Bangladesh
}

\author{
Md.Farid Hossain Talukder* Md.Yahin Hossain** Md. Nahin Hossain*** \\ *Lecturer, Faculty of Business, Bangladesh University of Business \& Technology (BUBT), Dhaka, Bangladesh. \\ **Lecturer, School of Business, University of Information Technology \& Science (UITS),Dhaka, Bangladesh. \\ *** Lecturer, School of Business, University of Information Technology \& Science (UITS),Dhaka, Bangladesh.
}

\begin{abstract}
The study was conducted to explore the extent of human resource management (HRM) usually practiced by five prominent commercial Banks of Bangladesh. The survey activities were done by the combination of structured questionnaire, unstructured interview and observation methods in order to examine the issues involved in employee selection and recruitment, salaries and wages, job analysis methods, performance evaluation, audit promotion scheme, Training \& Development programs. In this paper a five point likert scale is used to measure major problems of HRM in commercial Bank and also record the employees' opinion on eight indicators to measure their levels of job satisfactions.
\end{abstract}

\section{Introduction}

Human resources are considered the most important assets of an organization, but very few organizations are able to fully harness its potential (Ahmed \& Schroeder 2002). Human resources system is a set of distinct but interrelated activities, functions and process that are directed at attracting, developing and maintaining or disposing firms' human resources (lado \& Wilson 1994). Banks, like any other firm, need to transform inputs into outputs at an efficient rate in order to maximize profitability and to survive under competitive conditions. Therefore, if a bank is using more resource in the process than is technically required, it will be operating below the "frontier" of efficiency. Chief among the resources is used to produce output is labor or human resources which typically consumes between one third and one half of the operating expenses (Jaffry \& Ghulam 2008 ). Human resources are the operative of other resources. So proper nurturing of them ensures the success of commercial bank.

Human resources in other words, well informed capable citizenry can improve the total ability of an organization, a society, a government agency and virtually of a country, of a nation (khan, 2003). Banking industries across the world are going through a series of rapid changes due in part to the pace of technological development. Use of automated teller machines (ATM), advance statistical models for risk management and Advance Ledger Posting Machines (ALPM) has transformed the way traditional banking activity was performed. Technological advancement has changed the nature of banks demand for employee to perform banking activities. Computer literate, skilled workers are in demand with better compensation on offer compared to that received by low paid clerical and subordinate workers even a few years ago (S. Jaffry et al. 2008).

Banking industry is the knowledge based industry. Knowledgeable and well equipped employee is essential to operate the business. People can be transformed in to human resources when they are equipped with adequate knowledge, skills and competencies (Roknuzzaman,2006).

Commercial banking system dominates Bangladesh financial sector. Bangladesh bank is the central bank of Bangladesh and the chief regulatory authority. The banking system is composed of four state-owned commercial banks, five specialized developments banks, thirty private commercial banks and nine foreign commercial banks. In Bangladesh most of the human resources related decisions are mainly taken by the central management. In different branches these decisions are just implemented (Afroj, 2012).

\section{Literature Review}

The modern view of HRM first gained prominence is 1981 with its introduction on the prestigious MBA course at Havard Business School (Price, 2004). The Human Resources, in its simplest sense, refer to manpower or people resources, who are engaged in any organizational settings to meet institutional goals by virtue of their physical and intellectual capacity (Roknuzzaman, 2006). Sarkul (2003) defines manpower as power available from or supplied by the physical as well as intellectual efforts of man. Effective HR practices are found to lead to positive organizational outcomes (Becker and Gerhart, 1996) such as turnover (Huselid, 1995) and productivity (Katz et al., 1987). HR practices are generally categorized into the following: hiring and selection practices, incentives and rewards, safety training, communication and feedback, worker participation, management commitment, and performance evaluation.

The implementation of human resource management policies in an organization requires HRpractitioners or professionals to take an active part in different organizational activities (Islam 2011). HRM 
policies and practices involve the development of how individuals should be managed and specific HR initiatives (Schuler, 2002). HRM policies and practice refers to the activities of planning, staffing, appraising, and compensating, training and development and labor relations. HR planning confirms the organization has right people at right number for the right position on right time.

Staffing is a major HRM practice that organization uses to help to co-ordinate and control their global operations (Schuler et al, 2002). Recruitment, selection and placement are the activities concerned with fining suitable people to fill job vacancies within organization (Molander, 1996).

Performance appraisal is a managerial tool to control individual performance in organizations in order to achieve maximum performance (Morley, 2004). Compensation should be more immaterial in nature. This might involve the person's career prospects, for example the opportunity to grow within the company or participate in international exchanges of information which allow him to get involved in strategic policy planning (Harzing and Van Ruysseveld, 1995).

Training and development are the systematic process concerned with facilitating the acquisition of skills, knowledge and attitudes which result in improved organizational performance. The lack of training and development strategies within organizations can be viewed negatively by graduates (Molander, 1996). Training is a hallmark of good management, and a task manager ignore at their peril. Having high potential employees does not guarantee they will succeed. Instead, they must know what the management want them to do and how to do that (Afroj, 2012).

HRM is being practiced either formally or informally to a greater or lesser extent in business enterprises regardless of their size (Moyeen and Hug, 2001). In the recent period of time Human Resource Management (HRM) practices became so familiar and momentous in every business sector of Bangladesh (Afroj, 2012).

There is, in fact, no comprehensive study found on overall HRM practices in Commercial banks of Bangladesh. In this state of affairs a study on this area is essential to uncover the significant facts. Those studies are endeavored for the same.

\section{Research objectives}

The overall objective of the study was to explore the status of human resource management usually practiced in the public university libraries in Bangladesh. More specifically, the study objectives were to:

- Look into the nature, type and professional categories of human resources deployed in Commercial banks of Bangladesh.

- Discover HRM issues including staff selection and recruitment, salaries, job analysis methods, performance evaluation, audit, and promotion, etc.

- Uncover sustaining developments programmes including education and training, IT-orientation, career development, management development.

- Inspect staff's opinion regarding different levels of their job satisfaction on the basis of some selected indicators.

- Outline major problems of HRM, and to suggest some measures for better HRM practice in commercial bank of Bangladesh.

\section{Methodology of the study}

The theoretical part of the study was based on the review of relevant literature published in conference papers, journals, books, authorized documents and different web sites. Along with literature review, the research used a combination of survey and observation methods. The survey was conducted in Head office of five renowned Commercial bank of Bangladesh, which was chosen purposively. Table 1 lists the representative commercial bank of the study. Two separate questionnaires (one for the Banks' authority, and the other for Banks' staff) were designed to collect primary data. Five copies of one questionnaire were sent to the Bank authorities of five Banks to collect Bank related data. Copies of another questionnaire were given to 100 employees of five banks at professional, managerial, and official levels to receive their opinions on different aspects of their present job. The employees were selected on the basis of purposive sampling technique. Unstructured interview of the employee was also arranged for the clarification of data. The findings of the study were statistically analyzed.

\begin{tabular}{l|ll|} 
Sl. & Name of the bank & Location \\
\hline 1 & Prime Bank Ltd. & Dhaka \\
2 & United Commercial Bank Ltd. & Dhaka \\
3 & Dhaka Bank Ltd. & Dhaka \\
4 & Al-Arafah Bank Ltd. & Dhaka \\
5 & Jomuna Bank Ltd. & Dhaka
\end{tabular}




\section{Data analysis and discussion \\ Nature of Professional categories of Banks' human resources}

The study observed three categories of human resources working in the commercial bank of Bangladesh: professional, semi-professional, and non-professional. Major professionals and semi-professionals have been designated as CEO and Managing Director, Deputy Managing Director and Head of Divisions, General Manager, Assistant General Manager, Senior executive to officer etc. The rest of the staffs designated receptionist, clerks and cash department are considered as non-professionals. Table 2 shows that the larger portion $75 \%$ of the total 500 human resources working in the commercial Bank had professional background with post graduate Diploma in Bank Management or BBA and MBA in respectable field, while only $8 \%$ staff had non professional background with Bachelors and/or Masters in Science/Arts, and 17\% had short-term certificate course. United Commercial Bank (UCBL) was comparatively better in employing almost $42 \%$ professional staff followed by Dhaka Bank ltd (DBL) (33.3\%), Prime Bank ltd (PBL) (26.1\%), Al-Arafah Bank Ltd (AABL) (12.7\%) and Jomuna Bank Ltd (JBL) (12.1\%).

Table 2 Professional Employee's categories in different Banks.

\begin{tabular}{|c|c|c|c|c|}
\hline \multirow[t]{2}{*}{ Name of Banks } & Professional Grade & & \multicolumn{2}{|c|}{ Total Number of } \\
\hline & Non Professional & Semi Professional & Professional & Staff \\
\hline UCBL & $23(23 \%)$ & $35(35 \%)$ & $42(42 \%)$ & 100 \\
\hline DBL & $55(55 \%)$ & $22(22 \%)$ & $33(33.3 \%)$ & 100 \\
\hline PBL & $62(62 \%)$ & $12(12 \%)$ & $26(26.1 \%)$ & 100 \\
\hline AABL & $75(75 \%)$ & $12(12 \%)$ & $13(12.7 \%)$ & 100 \\
\hline JBL & $84(84 \%)$ & $4(4 \%)$ & $12(12.1 \%)$ & 100 \\
\hline
\end{tabular}

Table 3

Minimum Educational Qualification of the employee

\begin{tabular}{|c|c|}
\hline Category of staff & Educational Qualification \\
\hline Professional & $\begin{array}{l}\text { Graduate with Business administration (Accounting, Finance, Banking, Marketing, Management) to BBA, } \\
\text { Masters/MBA/MBM or PhD. }\end{array}$ \\
\hline Semi-professional & Honors, Masters (Economics, Math, English) Certificate course in Banking, Diploma in Banking, \\
\hline Non-professional & From Secondary School Certificate (S.S.C) to Master Degree (any discipline). \\
\hline MLSS & Minimum class VIII \\
\hline
\end{tabular}

\section{Recruitment and selection of employee}

Bank follows systematic procedure in recruitment and selection activities. For personnel Recruitment and Selection these banks follows some standard most of the cases. The practiced arrangement for selection and recruitment is the corporate decide what positions will have to fill and how to fill the immediate as well as future requirements. This total procedure is designed to cover all positions from bottom to top level. Succession planning is done by the higher authority to identify and forecast demand and source of HR (Afroj 2012).

It describes how to employ, monitor the employees and where to set them. By using the computer based information system-HRIS \& Skill Inventory helps estimate current and future employee's requirement. This information system also records the average employee demand and transfers of employee from one branch to another. Table 3 lists minimum educational qualification of different categories of the employees for their fresh or departmental recruitment.

Employment is always in formal basis and generally freshers are encouraged to apply for entry level position. Leave vacancies, transfers and promotion are the secondary techniques for the employment of medium and higher level positions. The surveyed banks, in selection process, use successive hurdle system. They followed a series of procedural steps, viz. completion of application form, employment test, comprehensive interview (written test, viva, presentation), and final employee selection.

\section{Job analysis}

Job analysis involves collecting information about the characteristics of a job using one of several methods: observation, interviewing, questionnaires, or more specialized job analysis methods such as position or functional analysis. Organizations sometimes use a combination of job analysis methods (Hawthorne, 2004; Mathis \& Jackson, 1997). All the Banking authorities reported that they follow a combination of several methods for job analysis of the employee. 
Table 5 reveals that two (40\%) Banks applied observation, individual interviews, and group interviews as a technique of employees' job analysis. Four (80\%) banks applied functional job analysis and Position Analysis Questionnaire and three banks (60\%) applied technical conference.

Table 5 Job analysis

Methods of Job Analysis

Observation

Functional job Analysis

Individual interviews

Group interviews

Position analysis questionnaire (PAQ)

Technical conference

\begin{tabular}{|cc|}
\hline No. of Bank & Percentage of the Bank \\
2 & $40 \%$ \\
4 & $80 \%$ \\
2 & $40 \%$ \\
2 & $40 \%$ \\
4 & $80 \%$ \\
3 & $60 \%$
\end{tabular}

\section{Performance evaluation, audit and promotion of the staff}

Banking sector is very competitive in nature. Usually employees have to frequently move to positions of greater responsibility within the organization as their experience and performance improve. A business unit of the bank is totally performance oriented. Employees of that units promotes according to their performance. Annual Confidential Report (ACR) was normally used as an important tool for the evaluation of employees' performance, which had a great impact on their future up-gradation particularly for MTOs (Management Trainee Officer). In business unit variables of performance are the ratio of loan recover, new customer creation etc.

Under the central banks supervision program, all employees of the bank would have to come within the scope of audit. Each and every bank has its own auditing activities which are known as internal audit. Usually external audit is done by the Bangladesh Bank (BB).

The attendance/absenteeism of the employee was measured through daily card punching system. Employer of beginner grade as junior officer, probationary officer could gradually be promoted to senior officer, principle officer and Senior Principle Officer considering their service length or time scale, salary grade, service experience, satisfactory ACR, and other qualifications.

\section{Human Resource Development (HRD) programmes}

As a major functional area of HRM, HRD has traditionally had three functions: training and development, organizational development, and career development (Hawthorne, 2004). Banking sector is well known for its knowledge base activities. Continuing education and training programmes are essential considerations to enrich their careers and excel their development.

Table 6 Human Resources Development program supported by Banking Institute

\begin{tabular}{|l|cc|}
\hline Training and development & No. of Bank & Percentage of the Bank \\
Organizational development & 5 & $100 \%$ \\
IT-orientation & 4 & $80 \%$ \\
Career development & 3 & $60 \%$ \\
Employee orientation & 3 & $60 \%$ \\
Capacity building & 5 & $100 \%$ \\
Leadership and supervisorial development & 3 & $60 \%$ \\
\hline
\end{tabular}

Banking activities and knowledge is ever changing. In order to cope up with these changes and to develop employees' careers all banks established their own training institute. Those institutes organized different types of training and development programmes based on the employees need. Those needs are identified by need assessment activities.

Whether any employee is newly recruited or transferred from one place to another, they need to adapt the working environment. Otherwise they may not give their best for the organization. For the adaptation in the new work responsibilities or working place, the employees may get help from the organizational policy. On the job training is a very effective mechanism for the proper orientation of new employees. Form the collected data on various employees; it is found that they are introduced to their new job by maintaining the organizational policy. Most of the employees especially who just introduced in the job, get a fresh and effective orientation 
from their organization as well as from the branch. Those who enter into the job as Management Trainee or Probationary officer always get 1-3 years probationary period with training to adapt and learn much about their job responsibilities and organizational rule (Afroj, 2011).

Commercial banks of Bangladesh regularly undertake such programmes. Obtaining banking diploma degree is mandatory for Management Trainee or Probationary officer. There is a huge opportunity for the novice banker to develop their careers by any local or foreign scholarships or fellowship programmes. In most cases, the banks organize to manage fellowships or scholarships by their own initiatives for training and higher studies program for bright employees.

As can be seen in Table 6, only two banks (40\%) support leadership and supervisorial development programmes, three banks (60\%) support capacity building, IT orientation, career development while four banks (80\%) claimed to support organization development, and five banks (100\%) organize orientation programmes for new and old employees.

\section{Information technology and human resources (in banking sector)}

As a part of stepping towards e-banking, the Foreign Commercial Banks have played the pioneering role with adoption of modern technology in retail banking during the early 1990s whereas the state-owned commercial banks and Private Commercial Banks came forward with such services in a limited scale during the late 1990s. Moreover, the banking industry as a whole, except for the four specialized banks (SBs), rushed to offer technology based banking services during the middle of the current decade. The existing form of e-banking that satisfies customer demand in banking activities electronically throughout the world are PC banking or PC home banking that include online banking, internet banking, mobile banking, and Tele banking (Rahman,2008 ).

Therefore, human resources working in banks must be equipped with ICT-based knowledge, skills and competencies. It is important to have banking related knowledge but having IT knowledge is essential to do the banking activities. All paper activities in bank is now transformed in to e-paper activities. So IT orientation training is done by 60 percent bank of Bangladesh.

But the survey shows (Table 7) that among 500 employee of five banks, only 20 (4\%) had IT background with short-term certificate courses, 350 (70\%) had minimum knowledge on IT, and a small number of employee, i.e. $130(26 \%)$ had no knowledge of IT. IT department of those banks regularly organize seminar and workshops when banks install new software in their operation.

Table 7 Condition of IT background of the Employee

\begin{tabular}{|c|c|c|}
\hline Condition of IT knowledge & No. of Employee & Percentage \\
\hline Moderate knowledge on IT & 20 & $4 \%$ \\
\hline Minimum knowledge on IT & 350 & $70 \%$ \\
\hline No IT knowledge & 130 & $26 \%$ \\
\hline Total & 500 & $100 \%$ \\
\hline
\end{tabular}

\section{Challenges of Human Resource Management (HRM)}

According to the Hudson report (2008) the critical HR challenges are hiring right staff, retaining talent, cutting staff, staff development, salary inflation, external threats, etc. The other challenges are changing working conditions, re-skilling, and compensation coping with the massive technology adoption program-change management from employees' as well as customers' perspectives. Banks' authorities and employee of five banks were asked to grade the problems they usually faced in HRM. Six major problems were identified, and a five-point Likert scale was used to measure the importance of the problems. Using statistical tools problems are analyzed in table 8.

Table 8 Problems in Human Resources Management in Bank

\begin{tabular}{|c|c|c|c|}
\hline Nature of the problem & No. of Bank & Mean score & Standard deviation \\
\hline Marketing of HR services & 5 & 3.8 & 3.3 \\
\hline Man-power planning & 5 & 4 & 3.8 \\
\hline Talent management & 5 & 4.3 & 3.5 \\
\hline New approach to performance management & 5 & 4.2 & 3.3 \\
\hline $\begin{array}{l}\text { Towards a framework for continuous development and } \\
\text { learning }\end{array}$ & 5 & 4.5 & 4 \\
\hline Improper HR policy & 5 & 4.5 & 4 \\
\hline Lack of ICT-literate personnel & 5 & 3.2 & 3 \\
\hline
\end{tabular}


Table 8 reveals that lack of continuous development and improper HR policy were two of the extremely important problems with the same mean score of 4.5, and same standard deviation of 4. Bank authorities reported lack of new approach to performance management, and failure in talent management become very important problems with mean score of 4.2 and 4.3, respectively. Lack of man power planning programs in bank become also a very important problem with means score of 4 . And remaining two important problems within the bank were lack of ICT-literate personnel and Marketing of HR services with mean score of 3.2 and 3.8 having standard deviation of 3 and 3.3 .

\section{Job satisfaction}

Employees of different categories were examined to learn their levels of job satisfaction on the basis of 9 indicators. Job satisfaction is a function of the degree to which one's personal needs are fulfilled in the present job situation. In this study five-point Likert scale is used to record the responses of the employee regarding job satisfaction.

Table 9 reveals that the employees were "satisfied" on 5 indicators with mean scores ranging from 3.90 to 4.0. Salary scale was ranked as 1 st with mean score 4.0 followed by present job position with mean score 4 , leave policy mean score 3.5, working hour mean score 2.5. Employees are highly satisfied with compensation and mean score is 4.4 followed by staffing system (mean score is 3.9) working condition (mean score is 4). Status of the bank job is always high having mean score 4.3 followed by ample opportunities of career growth (mean score is 4).

Employees strongly argued that they are not satisfied with the recent HR policies and practices exercised in the bank. The most significant consideration of the study was that the mean scores of six variables were minimum 4. That means except leave policy and working hour all indicators are satisfactory to employees.

Table 9 Job satisfaction levels of the employee

\begin{tabular}{l|clll}
\hline Ranking & Indicators & $\boldsymbol{N}$ & Mean & Standard deviation \\
$\mathbf{1}$ & Salary & 60 & 5 & 4.8 \\
$\mathbf{2}$ & Job position & 60 & 4 & 3.8 \\
$\mathbf{3}$ & Leave policy & 45 & 3.5 & 3 \\
$\mathbf{4}$ & Working hour & 56 & 2.5 & 2 \\
$\mathbf{5}$ & Compensation & 50 & 4.4 & 4.1 \\
$\mathbf{6}$ & Staffing system & 50 & 3.9 & 3.5 \\
$\mathbf{7}$ & Working condition & 50 & 4 & 3.8 \\
$\mathbf{8}$ & Status of the job & 50 & 4.3 & 4 \\
$\mathbf{9}$ & Career growth & 50 & 4 & 3.8 \\
Scale: 1 - not satisfied; 2 - satisfied to some scope; 3 - moderately satisfied; 4 - satisfied; 5- highly satisfied. &
\end{tabular}

\section{Major findings of the study}

All Commercial Banks in Bangladesh are almost same in their nature, functions, programmes, employing human resources. Nonetheless, the major findings of the study were:

- There were a good number of professional and qualified human resources in each of the surveyed bank. On an average, $75 \%$ of staffs were professionals, $18 \%$ were semi-professionals and the remaining $7 \%$ percent were non-professionals. Among the professionals most of them were MBA or BBA holders.

- There was a great shortage of ICT-literate manpower in the banks. Only 4\% staff had professional IT background with short term certificate course(s), while $70 \%$ had minimum knowledge on IT, and the rest of the staff $(26 \%)$ had no IT knowledge.

- The study found that each bank has its own training institute for human resource development activities but there is no proper HR information system in any of the surveyed banks. All human resources were centrally managed by their respective headquarters'.

- All banks followed same procedural steps for selection and employment of qualified employees: completion of application form, employment test ( $\mathrm{Cv}$ scrutinize, written, viva-voce), comprehensive interview (simulation test, presentation, case analysis), and final employee selection.

- There was a regular practice among the surveyed banks with regard to promotion of human resources from junior grade to upper grade considering their performance, time scale, salary grade, service experience, satisfactory ACR, and other conditions and qualifications imposed by the Bangladesh Bank under the promotion or up-gradation of the rules. 
- The study reveals that two (40\%) Banks applied observation, individual interviews, and group interviews as a technique of employees' job analysis. Four (80\%) banks applied functional job analysis and Position Analysis Questionnaire and three banks (60\%) applied technical conference.

- Compared to the public bank, human resources employed in private bank in Bangladesh were getting more privileges. They were more satisfied with salary scale, present job position and compensation. But employees are not satisfied with working hour, leave policy and hr policy. Employees strongly argued that they are not satisfied with the recent HR policies and practices exercised in the bank. The most significant consideration of the study was that the mean scores of six variables were minimum 4 . That means except leave policy and working hour all indicators are satisfactory to employees. Finally banks have ample opportunities for career growth.

\section{Recommendation}

On the basis of the findings of the study the Following recommendations are made for better HRM practice in the banks of Bangladesh:

- Provision should be created to employ professional staffs having graduate and/or postgraduate degrees in Information technology at IT department of banks. Educational qualifications, Experiences, skills, competencies, and ICT-literacy of the potential candidates are given emphasis in the selection and recruitment process of employees.

- The salary package and administrative status of private banks are truly attractive. But in public banks salary restructuring is needed to motivate employees.

- To develop human resources, the bank should undertake different HRD programmes including continuing education and training, IT-orientation, career development, etc. Banks' have good number of bright employees and it should create opportunities for employee's higher studies with fellowship/scholarship at home and abroad.

- Banks should organize seminars, workshops, conferences, different short courses, and training programmes on financial matters, current issues, software up gradation on regular basis that would definitely help to develop knowledgeable manpower, create awareness and change mental attitudes among the professionals.

- All banks and supporting bodies should allocate sufficient budget and sends competent employees to international conferences and seminars to prepare them for the competitive knowledge market of $21^{\text {st }}$ century.

- The banks should apply standard techniques for employees' job evaluation, performance measurement and audit as a routine work. On the basis of the result, their duties and responsibilities should be redesigned and restructured. Because it will reduce the repetitive work and reduce monotonous environment.

- Banks have a separate human resources departments. But it is essential to empower the department or divisions for handling different issues in HRM in banks. The divisions should be incorporated with wellorganized HRIS (human resource information systems) and modern IT facilities.

\section{Conclusion}

The success of banks largely depends on the intellectual development of the employees. Along with intellectual development of the knowledge worker, technical infrastructures of the bank must be ensured to enhance the effectiveness of the employee and the bank. Generally, the banking profession in Bangladesh is recognized with standardized salary scale, higher social status and dignity. As can be found from the study, human resources in banks were enjoying comparatively better facilities under the rules of banking industry. Employees of the bank getting good number of bonus and compensation, including salary grade, leave facilities, housing facilities, gratuities, provident funds, and losses of accident or death of employees etc. The employees in private bank are more satisfied with salary scale, job position, promotion scheme, working environment but very worried about working hours and work pressure. Most of the employees are less satisfied with HRM polices and practice, job analysis, IT facilities, job evaluation and performance measurement technique. Human resources have been centrally managed by all surveyed bank. Bank should decentralize their HR activities in all branches and develop strong HR polices. Authority and responsibility should be properly distributed to all HR managers. Bank should give some significant power and role to HR director in order to empower the HR departments.HR department in banking sector of Bangladesh is comparatively ineffective than India, Pakistan and Sri-Lanka because of their lack of empowerment facilities. The proper empowerment of HR department means their participation in preparing management policies, plan and program, forecasting demand and supply of human resources and in policy formulation and implementation. This will help to recruit and maintain skilled, knowledgeable and well performed workforce to meet current and future organizational as well as individual needs. 


\section{References}

[1]. Ahmad, Nasiruddin (1994). Personnel requirements in the libraries of Bangladesh. International information and library Review, 26(4), 315-326.

[2]. Bryson, Jo (1996). Effective library and information centre management. Delhi: Jaico Publishing House.

[3]. de Silva, Sriyan (1997). Human resources development for competitiveness: A priority for employers. Paper presented at the ILO Workshop on Employers' Organizations in Asia-Pacific in the twenty-first Century, Turin, Italy, 5-13 May.

[4]. Gaddagimath, Ravi, B., \& Jange, Suuresh (2000). Changing libraries: Competencies and challenges for university librarians. In T. Ashok Babu, et al. (Eds.), Vision of future library and information systems (pp. 14-18). New Delhi: Viva Books.

[5]. Hawthorne, Pat (2004). Redesigning library human resources: Integrating human resources management and organizational development. Library Trends, Summer.

[6]. Human Development Report. (2000). Human development index. New York: UNDP.

[7]. Khan, Md. Shahabuddin (2003). Reading promotion: Perspective Bangladesh, CDN LAO newsletter, No. 48, November, at: /http://www.ndl.go.jp/en/publication/cdnlao/048/481.html last, accessed on 12 June, 2006.

[8]. Mannan, S. M., \& Begum, Suraiya (2002). Development of libraries in Bangladesh: A study of the historical route. Nibandhamala (collection of research articles), Vol. 11(p.222). Centre for Advanced Research in the Humanities, Dhaka University.

[9]. Mathis, Robert, L., \& Jackson, John, H. (1997). Human resource management (8th ed). Minneapolis/St. Paul, MN: West Publishing

[10]. Price, Alan (2004). Human Resource Management in a business context. At /http://www.hr- opics.com/introduction-tohrm/frompersonnel.html last, accessed on 29 August 2005.

[11]. Sarkhel, Juran Krishna (2003). Development of human resources for library and information services: Perspectives and issues. Paper presented at the International Conference on Role of Libraries in Human Resource Development in Bangladesh, Rajshahi, December 20 .

[12]. Simmons-Welburn, Janice, \& McNeil, Beth (2004). Human Resource Management in today’s academic library: Meeting challenges and creating opportunities. Oxford: Greenwood Publishing.

[13]. The world Factbook (2006). At /https://www.cia.gov/cia/ publications/factbook/geos/bg.html, last accessed on 21 December 2006.

[14]. Wilson, Louis Round, \& Tauber, Maurice Falcolm (1966). The University Library (2nd ed). New York: Columbia University Press.

[15]. Arthur, J. B. (1994). Effects of human resource systems on manufacturing performance and turnover. Academy of Management Journal, 37, 670-687.

[16]. Barney, J. (1991). Firm resources and sustained competitive advantage. Journal of Management, 17, 99-120.

[17]. Barney, J. B. (1995). Looking inside for competitive advantage. Academy of Management Executive, 9, 49-61.

[18]. Barney, J., \& Wright, P. M. (1998). On becoming a strategic partner: The role of human resources in gaining competitive advantage. Human Resource Management, 37, 31-46.

[19]. Beamish, P. W. (1993). The characteristics of joint ventures in the People's Republic of China. Journal of International Marketing, 1, 29-48.

[20]. Becker, B., \& Gerhart, B. (1996). The impact of human resource management on organizational performance: Progress and prospects. Academy of Management Journal, 39, 779-801.

[21]. Bjorkman, I., \& Fan, X. (2002). Human resource management and the performance of western firms in China. International Journal of Human Resource Management, 13, 853-864.

[22]. Caplan, J. (2003). The battle for talent: Are there really no rules of engagement? China Staff, 10, 1-5.

[23]. Cheng, D. (2005). Exploring the ways to build an effective SOE managerial rewarding system (Jianquan Guaoqi Jingyingzhe jili jizhi de ruogan duice). Enterprise Economy (Qiye Jingji) (in Chinese), 4, 35-37.

[24]. China State Statistics Bureau. (2005). China statistical year book. Beijing: China Statistics Publishing House (Zhongguo tong ji chu ban she).

[25]. Delaney, J. T. (1997). Unions, human resource innovations, and organizational outcomes. In D. Lewin, B. Kaufman, \& D. Sockell (Eds.), Advances in industrial and labour relations (Vol. 7, pp. 207-245). Greenwich, CT: JAI Press.

[26]. Delaney, J. T., \& Huselid, M. A. (1996). The impact of human resource management practices on perceptions of organizational performance. Academy of Management Journal, 39, 949-969.

[27]. Delery, J. E., \& Doty, D. H. (1996). Modes of theorizing in strategic human resource management: Tests of universalistic, contingency, and configurationally performance predictions. Academy of Management Journal, 39, 802-835.

[28]. Deng, H. (2005, May 13). The development of the reform of China's state-owned enterprise. Guangming Daily (in Chinese).

[29]. Moyeen, AFM, Abdul and Huq, Afreen, (2001), "Human Resource Management Practices in Business Enterprises in Bangladesh", Dhaka University Journal of Business Studies, Vol. XX11, No.2, December 2001, ISSN 1682-2498. pp. 29-35.

[30]. Ahmed, Faruq, and Bhuiyan, Mohammad, Moqbul, Hossen, (2002), “Experiences of Bangladeshi Companies in Strategic Human Resource Management”, Dhaka University Journal of Business Studies, Vol. XX111, No. 1, June, 2002, ISSN 1682-2498. pp. 97106.

[31]. Mohiuddin, Mohammad and Mahmood, Monowar, Hossain, (2001), " Personnel to Human Resource Management", Dhaka University Journal of Business Studies, Vol. XX11, No. 2, December, 2001, ISSN 1682-2498. pp. $53-65$.

[32]. Aurther, William, and Davis, Keith, “Human Resource Management”, (9th edition), McGraw-Hill Book Company, New York, 2005. pp.35-60.

[33]. Dessler, Gary, (2006), “Human Resource Management”, (11th edition), McGraw-Book Company, Boston, 2006. pp.54-62.

[34]. Robbins, Stephen, P, and DeCenzo, (2004), "Human Resource Management", (12 ${ }^{\text {th }}$ edition, New Wally \& Sons, New York, 2004. pp. 55-68.

[35]. Human Resource Management and Expatriate: http// www. hrmexp.com/ Retrieved date June 25, 2007.

[36]. Human Resource Management of BCCP, Bangladesh: http// www. hrm. bccpba. com/Retrieved date May 31,-2007.

[37]. Anthony, William, P. and Others, (2003), "Strategic Human Resource Management",(6th edition), McGraw-Hill Book Company, Boston, USA-2003.pp.67-78.

[38]. Human Resource Management Practices in Bangladesh: http// www. hrmpb.com/ Retrieved date June 20, 2007.

[39]. Human Resource Management Practices in the 21st Century: http// www.hrmp21.com/ Retrieved date May10, 2007.

[40]. Rahim, Abdur, Shake, (2007), " Role of Technology in Changing the Human Resource Management Practices: An Exploratory Study", Southeast University Journal of Business Studies, Vol.4, No.2, ISSN 1815-3267.pp.23-30.

[41]. The Annual, Report of BCCP, Bangladesh 2006 